\title{
Efektivitas Penghapusan Barang Milik Daerah Pada Sektor Keuangan di Sekretariat DPRD Kota Bandung
}

\author{
${ }^{1}$ Vanessa Wulandari Oksantiarozen, ${ }^{2}$ Herabudin, ${ }^{3}$ Herry Sutanto \\ ${ }^{1}$ UIN Sunan Gunung Djati Bandung, Indonesia; vanessawulandari24@gmail.com \\ ${ }^{2}$ UIN Sunan Gunung Djati Bandung, Indonesia; herabudin@uinsgd.ac.id \\ ${ }^{3}$ UIN Sunan Gunung Djati Bandung, Indonesia; herrysutanto@uinsgd.ac.id
}

\begin{abstract}
The deletion of property belonging to this area is carried out in the absence of the ruler or the power of the user of the goods who has been transferred to the ownership of the destruction that has occurred or for other reasons, this deletion is carried out in the presence of a regional head who makes a decision and acts as the manager of the goods. Regional ownership (BMD) is a problem that is considered insignificant. The purpose of this study was to determine the effectiveness of the elimination of regional property on finance at the Secretariat of the DPRD City of Bandung, the obstacles and efforts to minimize these problems or obstacles. The theory used by Dunn for adequacy and responsiveness. Researchers used a qualitative research method with a descriptive approach. Primary data sources used were field surveys and interviews; secondary data used is directly from the Head of Asset and Household Section and Asset and Household Staff. The data analysis technique used was the Miles and Hubberman model. The results of this study show that the effectiveness of the elimination of regional property in finance is eliminated by means of an auction / tender; barriers to delivery of goods are severely damaged, lost or unknown, the goods to be written off are no longer intact; efforts have been made to minimize these obstacles or problems. namely the same as the explanation in the first point by way of the auction / tender.
\end{abstract}

Keywords: Local Government, Effectiveness, removal, Finance

\section{Pendahuluan}

Barang yang dapat diperoleh ataupun dibeli oleh beban Anggaran Pendapatan dan Belanja Daerah (APBD) serta berasal dari perolehan meliputi hibah ataupun sumbangan yang sejenisnya sebagai perjanjian kontrak berdasar ketentuan Undang-Undang dan juga dapat diperolehkan berdasar hasil putusan-putusan pengadilan serta dapat diperoleh dari kekuatan-kekuatan hukum yang ditetapkan Barang milik daerah. Pada bidang pengelolaan barang milik daerah ini terdiri dari beberapa yaitu perencanaan kebutuhan dan anggaran, penerimaan, pengadaan, penghapusan, penatausahaan dan juga sebagainya. Barang milik daerah berkaitan dengan aset, aset yaitu merupakan ekonomi sumber daya serta dapat dimiliki ataupun dikuasai oleh pemerintahan hal ini dari akibat berbagai peristiwa pada masa lalu pemanfaatan sosial dan ekonomi masa depan yang dapat memperoleh secara baik oleh pemerintahan ataupun oleh masyarakat sekitar dapat diukur dalam satuan uang sumber daya yang termasuk bukan keuangan yang dapat memerlukan dalam penyediaan jasa-jasa bagi semua sumber daya masyarkat yang dapat dipelihara karena berbagai alasan budaya dan sejarah. Pengelolaan aset daerah dikatakan sebagai salah satu elemen yang sangat penting dalam suatu pengelolaan keuangan pemerintahan daerah.

Salah satu contoh dari pengelolaan aset yaitu penghapusan, penghapusan yaitu merupakan suatu tindakan menghapus daftar dari pengguna barang ataupun pengguna kuasa dari sebuah daftar inventarisasi barang milik daerah (BMD). Barang dihapuskan ini dilakukan dengan penertibitan 
suatu keputusan dari kepala daerah tentang penghapusan BMD. Hal inilah dalam penghapusan barang milik daerah menyatakan sebuah proses tindak lanjut dari pengelolaan barang milik daerah serta mempunyai tujuan untuk membebaskan dari sebuah kepengurusan yang sudah memenuhi beberapa kriteria, dilakukan untuk sebuah tindak lanjut penghapusan dari tanggung jawab administrasi serta fisik barang yang sudah berada dalam berbagai bendahara barang yang dikelola, pengurusan barang dan pengguna barang hal ini berdasar ketentuan undang-undangan yang berlaku.

Pada persoalan tentang dihapusnya BMD inilah menjadi suatu persoalan yang diduga tidak ringan. Jika didapati suatu barang yang tidak ada pengendaliannya serta penguasanya terhadap sebuah dinas pemerintahan dan tidak ada supervisi persoalan tersebut dari barang milik daerah yang dihapuskan, maka dimungkinkan sangat minim kondisi ini lahir yang di mana barang tersebut belum dihilangkan dan tidak dapat digunakan atau tidak membantu pada sebuah operasional kegiatan pemerintah, meski secara implisit akan dikenakan biaya pemeliharaan dan pengadaan barang milik Daerah/Negara terhadap pengelolaan akan tetapi diajukan anggaran biaya pemeliharaan. Hal inilah yang menjadi salah satu alasan mengapa perlunya penindakan pada penghapusan barang milik Daerah/Negara. Berikut tabel rincian rincian belanja barang dan belanja peralatan dalam kondisi rusak berat yang diusulkan untuk dihapuskan di Sekretariat DPRD Kota Bandung:

Tabel 1

Rincian Belanja Barang dan Belanja Peralatan Dalam Kondisi Rusak Berat Yang Diusulkan Untuk Dihapuskan

\begin{tabular}{cc}
\hline Jenis Belanja & Total \\
Belanja Peralatan & 3.523 .292 .350 \\
Belanja Barang & 1.445 .929 .888 \\
Jumlah & 4.969 .222 .238 \\
\hline
\end{tabular}

Sumber: Sekretariat DPRD Kota Bandung 2019

Pada Pada tabel 1 diatas belanja peralatan sebesar Rp 3.523.292.350 dan belanja barang sebesar Rp 1.445.929.888 dengan jumlah Rp 4.969.222.238 merupakan barang dalam kondisi rusak berat yang belum dilaksanakan pengahapusan maka diusulkan untuk dihapuskan.

Berdasarkan hasil observasi peneliti bahwa permasalahan yang ada di Sekretariat DPRD Kota Bandung diantaranya adalah efektivitas penghapusan keuangan barang milik daerah di Sekretariat DPRD Kota Bandung, hambatan-hambatan yang ada dalam penghapusan keuangan barang milik daerah di Sekretariat DPRD Kota Bandung, dan upaya apa saja yang telah dilakukan untuk meminimalisir hambatan atau masalah penghapusan barang milik daerah.

Menurut Putri (2019), administrasi keuangan adalah aktivitas pengaturan dalam pengadaan dan penggunaan keuangan dalam rangka menciptakan kegiatan organisasi kerja seperti perencanaan, pertanggung jawaban, dan pengawasan keuangan. Sedangkan bagi Anggara (2016) keuangan negara adalah pengelolaan kekayaan oleh pemerintahan, dan juga uang, barang yang dimiliki oleh kertas berharga bernilai uang serta dimiliki juga oleh kewajiban dan juga hak serta dinilai oleh uang. (Mahmudi, 2011) keuangan daerah yaitu merupakan semua kewajiban dan hak pemerintah yang dapat dinilai oleh uang, serta juga segala sesuatu yang berwujud uang ataupun berupa barang. 
Efektivitas yaitu manfaat sumber daya, sarana serta prasarana yang jumhlahnya sangat tertentu secara sadar serta dapat menetapkan sebelumnya dalam penghasilan sejumlah barangbarang dan jasa kegiatan yang sudah dijalankan (Siagian,2002).

Suatu tindakan menghapus BMD dari berbagai daftar harga barang serta diterbitkan sebuah keputusan dari pejabat yang berwenang membebaskan pengelolaan barang, penggunaan pada barang ataupun pengguna kuasa barang dari pertanggungjawaban administrasi dan fisik berada dalam barang penguasaan yaitu Penghapusan (Sapjeriani, 2018). Peneliti menggunakan teori efektivitas kebijakan dari Dunn yaitu kecupukan untuk mengetahui seberapa jauhnya suatu tingkat efektivitas dapat memuaskan kebutuhan, nilai, dan kesempatan yang menumbuhkan adanya suatu masalah dan responsivitas seberapa jauh untuk mengetahui suatu kebijakan.

\section{Metode Penelitian}

Penelitian yang digunakan penulis yaitu menggunakan penelitian kualitatif dengan menggunakan metode deskriptif karena sesuai dengan permasalahan yang diambil oleh penulis dan penelitian yang dilakukan bersifat mendeskripsikan suatu masalah secara mendalam. Teknik pengumpulan data dalam penelitian ini yakni dengan studi kepustakaan dan studi lapangan. Studi kepustakaan yang didapatkan oleh penulis berupa referensi dari buku, jurnal, skripsi serta situs internet yang berhubungan dengan penelitian yang dilakukan oleh penulis, Studi lapangan dalam penelitian ini yakni dengan observasi, wawancara dan dokumentasi. Dalam teknik observasi ini peneliti melakukan pengumpulan data dengan observasi kepada Kasubag aset dan rumah tangga dan kepada pihak-pihak lainnya yang mendukung dalam data-data dalam pembahasan penghapusan barang milik daerah.

Dalam teknik wawancara, peneliti mengajukan pertanyaan terkait judul penelitian kepada informan untuk memperoleh informasi terkait permasalahan yang dibahas. Dalam penelitian ini peneliti menggunakan teknik wawancara terstruktur yaitu dengan menyiapkan pertanyaan untuk semua semua responden, wawancara langsung dilakukan di Sekretariat DPRD Kota Bandung. Berikut adalah nama-nama informan:

Tabel 2

Informan Penelitian

\begin{tabular}{cll}
\hline No & \multicolumn{1}{c}{ Nama } & \multicolumn{1}{c}{ Jabatan } \\
\hline 1 & H. Endy Purnama & Kasubag Aset dan Rumah Tangga \\
2 & Yana Jajang Priana & Staff Aset dan Rumah Tangga \\
3 & Agus Dudi Setiawan & Staff Aset dan Rumah Tangga \\
4 & Juju Efendi & Staff Aset dan Rumah Tangga \\
5 & Odik & Staff Aset dan Rumah Tangga \\
\hline
\end{tabular}

Sumber: Data Diolah oleh Peneliti 2020

Selanjutnya teknik dokumentasi dalam penelitian ini studi dokumentasi yang dipakai oleh peneliti berupa tabel dan data mengenai penghapusan barang milik daerah, untuk melengkapi data penelitian penulis memperoleh data secara langsung ke tempat penelitian di Sekretariat DPRD Kota Bandung. 
Dalam melakukan analisis data, penulis memanfaatkan model Miles dan Hubberman. Pertama berupa tahapan reduksi data, dimana terjadi suatu proses pemilihan, pemusatan perhatian pada penyederhanaan, abstrak dan juga transformasi data yang muncul dari catatan tertulis yang berada di lapangan. Kedua, yaitu tahapan penyajian data, yang merupakan pengumpulan informasi-informasi secara tersusun dan memunkinkan adanya suatu penarikan kesimpulan dan juga pengambilan dalam suatu tindakan yaitu penyajian data. Ketiga, yaitu tahap penarik kesimpulan, dimana pada tahapan ini penarikan kesimpulan yang dilakukan oleh penulis berdasarkan pada bab-bab hasil pembahasan yang sudah dideskripsikan, sehingga berdasarkan pembahasan penulis dapat menarik kesimpulan sesuai dengan rumusan masalah.

\section{Hasil dan Pembahasan}

Bahwa dalam penghapusan barang milik daerah pada keuangan dijelaskan dalam buku (Pengadaan Barang dan Jasa Perpres RI No 16 Tahun 2018) dengan cara tender/lelang, tender adalah merupakan suatu metode pemilihan untuk mendapatkan penyedia barang/pekerjaan kontruksi/jasa lainnya.

Tender ataupun seleksi internasional yaitu pemilihan berupa penyedia barang/jasa dengan peserta pemilihan dapat berasal dari pelaku usaha nasional dan pelaku usaha asing. Berdasarkan hasil wawancara dengan Kasubag Aset dan Rumah Tangga bapak H. Endy Purnama, beliau menyampaikan informasi tentang penghapusan barang milik daerah di Sekretariat DPRD Kota Bandung sebagai berikut:

"permasalahan yang ada disini tentang penghapusan barang milik daerah pada keuangan seperti meja, kursi, komputer, kendaraan operasional dan sebagainya belum dihapuskan, karena belum dilakukannya penghapusan maka perlu biaya yang cukup besar untuk biaya pemeliharan, perawatan maka dari itu barang-barang tersebut harus di lelang proses pengajuan lelang yaitu Sekretaris Daerah mengajukan ke Pemerintah Kota, pemerintah kota mengajukan ke WaliKota apabila WaliKota sudah menyetujui maka barang-barang tersebut di lelang. Barang-barang untuk di lelang memang belum dilakukan tetapi sudah dilakukannya usulan untuk dihapuskan”.

Berdasarkan pernyataan tersebut dapat disimpulkan bahwa penghapusan barang milik daerah pada keuangan itu harus dilakukan dengan cara lelang agar barang-barang tersebut tidak semakin rusak berat.

Di dalam penghapusan barang milik daerah ini juga mempunyai beberapa hambatanhambatan yang ada berikut adalah hasil wawancara dengan Kasubag Aset dan Rumah Tangga bapak H. Endy Purnama, beliau menyampaikan informasi tentang hambatan yang ada dalam efektivitas penghapusan barang milik daerah pada keuangan di Sekretariat DPRD Kota Bandung berikut:

"hambatan yang ada dalam efektivitas penghapusan barang milik daerah pada keuangan di Sekretariat DPRD Kota Bandung yaitu hambatannya biasanya barang yang akan dihapuskan sudah tidak utuh lagi, hilang atau tidak diketahui keberadaannya." 
Dari pernyataan tersebut dapat disimpulkan bahwa sebaiknya penghapusan barang milik daerah itu harus segera dilakukan agar barang-barang tidak semakin rusak berat dan tidak diketahui keberadaanya karena terlalu banyaknya barang yang akan di lelang. Berdasarkan hasil wawancara dengan Yana Jajang Priana, SE staff Aset dan Rumah Tangga beliau menyampaikan informasi tentang hambatan yang ada dalam efektivitas penghapusan barang milik daerah pada keuangan di Sekretariat DPRD Kota Bandung berikut:

"Dampak atau hambatannya itu pada penghapusan barang milik daerah barang sudah dalam kondisi rusak ringan dan rusak berat dan juga barangbarang menjadi rongsokkan jadi tidak bisa di lelang. "

Berdasarkan hasil pernyataan tersebut bahwa dapat disimpulkan hambatan dalam penghapusan barang milik daerah yaitu barang-barang yang tidak segera di lelang barang tersebut akan menjadi rongsokan dan tidak dapat digunakan lagi. Berdasarkan hasil wawancara dengan Odik staff Aset dan Rumah Tangga beliau menyampaikan informasi tentang hambatan yang ada dalam efektivitas penghapusan barang milik daerah pada keuangan di Sekretariat DPRD Kota Bandung berikut:

"hambatan-hambatan dari penghapusan barang milik daerah sama apa yang sudah di katakan oleh pak endy dan pak yana barang-barang tersebut bisa menjadi rusak berat apabila tidak segera dilakukan lelang, barang sudah tidak utuh hilang tidak diketahui keberadaannya karena terlalu banyak dan ada juga yang lupa menyimpan barang-barang tersebut dimana jadi barang tersebut terbengkalai."

Berdasarkan pernyataan tersebut dapat disimpulkan bahwa hambatan-hambatan pada penghapusan barang milik daerah pada keuangan yaitu banyak barang yang mengalami kerusakan baik yang rusak berat maupun rusak ringan ataupun barang sudah tidak utuh lagi bahkan hilang tidak diketahui keberadaannya.

Dengan beberapa hambatan yang ditemukan pada penghapusan barang milik daerah di Sekretariat DPRD Kota Bandung. Terdapat beberapa upaya yang dilakukan, upaya yang telah dilakukan untuk meminimalisir hambatan atau masalah pada penghapusan barang milik daerah sama seperti penjelasan pemasalahan yang pertama yaitu dengan cara lelang. Berikut berdasarkan hasil wawancara dengan Kasubag Aset dan Rumah Tangga bapak H. Endy Purnama, dan Juju Efendi staff Aset dan Rumah Tangga beliau menyampaikan informasi tentang hambatan yang ada dalam efektivitas penghapusan barang milik daerah pada keuangan di Sekretariat DPRD Kota Bandung berikut:

"upaya yang telah dilakukan dalam penghapusan barang milik daerah yaitu dengan cara lelang/tender sama seperti yang sudah dijelaskan dalam point pertama cara yang efektif dalam penghapusan barang milik daerah pada keuangan dilakukannya lelang/tender. Barang seperti kendaraan operasional, komputer, meja, kursi, lemari dan sebagainya itu dihapuskan dengan cara lelang/tender."

Berdasarkan pernyataan tersebut dapat disimpulkan bahwa upaya dalam penghapusan barang milik daerah pada keuangan sama seperti penjelasan rumusan masalah point pertama yaitu dengan cara lelang/tender barang tersebut dihapuskan dengan cara di lelang. 


\section{Simpulan}

Berdasarkan hasil penelitian yang sudah dilakukan oleh peneliti maka dapat diketahui bahwa efektivitas penghapusan keuangan barang milik daerah pada di Sekretariat DPRD Kota Bandung yaitu dengan cara lelang/tender barang-barang seperti meja, kursi, komputer, kendaraan operasional dan sebagainya tersebut dihapuskan dengan cara dilelang. Proses pelelangan yaitu Sekretariat DPRD Kota Bandung mengajukan kepada Pemerintah Kota setelah itu Pemerintah Kota mengajukan kepada WaliKota apabila Walikota sudah menyetujui maka dilakukan lelang, kemudian lelang di seleksi ada lelang/seleksi berhasil dan ada juga lelang/seleksi gagal. Hambatan-hambatan yang ada dalam efisiensi penghapusan barang milik daerah pada keuangan di Sekretariat DPRD Kota Bandung yaitu barang menjadi rusak berat, hilang atau tidak diketahui keberadaannya, sudah tidak utuh lagi bahkan barang-barang bisa menjadi rongsokan apabila tidak segera dilakukannya lelang. Upaya yang telah dilakukan untuk mengurangi persoalan atau hambatan pada penghapusan barang milik daerah, sama seperti penjelasan pada point pertama yaitu barang-barang tersebut dihapuskan dengan cara dilelang agar barang tidak semakin rusak berat dan tidak banyak mengeluarkan biaya untuk biaya perawatan dan pemeliharaan.

\section{Referensi}

Anggara, S. (2016). Administrasi Keuangan Negara.Bandung: CV Pustaka Setia.

Auliya, M. (2016). Pelaksanaan Penghapusan Barang Milik Daerah Di Dinas Bangunan Gedung dan Aset Daerah Kota Yogyakarta Tahun 2015.

Banga, W. (2017). Administrasi Keuangan Negara dan Daerah: Ghalia Indonesia.

Fransiska, F. T. 2014. (2014). Oleh:Pelaksanaan Penghapusan Barang Milik Daerah Berdasarkan Peraturan Menteri Dalam Negeri No.17 Tahun 2007 Tentang Pedoman Teknis Pengelolaan Barang Milik Daerah.

Gibson JL JM Invancevich, JH Donnelly, Organisasi. (2001). terjemahan Agus Dharma, Jakarta: Erlangga, hal 120. 1 19. 19-42.

Putri, A. A. (2019). Administrasi Keuangan. Administrasi Keuangan, 1-9.

Makmur. (2015). Efektivitas Kebijakan Kelembagaan Pegawasan: Refika Aditama.

Mahmudi. (2015). Manajemen Kinerja Sektor Publik: UPP STIM YKPN.

Ritonga, H.K. 2017. (2012). Efektivitas Pendayagunaan Dana Zakat Produktif Terhadap Pemberdayaan Mustahik Pada Dompet Dhuafa Kota Pekanbaru, 1-4.

Silalahi, U. (2006). Metode Penelitian Sosial.Bandung: Unpar Press.

Sugiyono. (2017). Metode Penelitian Kuantitatif, Kualitatif dan R\&D. Bandung: CV. Alfabeta

Sapjeriani. (2018). Diajukan Untuk Memenuhi Salah Satu Syarat Guna Memperoleh Gelar Ahli Madya Jenjang Studi Diploma III Program Studi Akuntansi. 21312027. 